Historic, archived document

Do not assume content reflects current scientific knowledge, policies, or practices. 



\section{MUSHROOM CASING SOIL IN RELATION TO YIELD}

By Edmund B. Lambert, pathologist, Division of Mycology and Disease Survey and Harry Humfeld, associate bacteriologist, Division of Soil Microbiology, Bureau of Plant Industry

\section{CONTENTS}

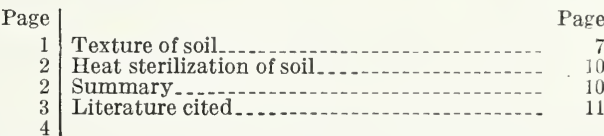

\section{INTRODUCTION}

Since the beginning of mushroom culture, growers have found it necessary to spread a shallow layer of soil over the beds in order to induce the mycelium in the beds to produce mushrooms. This layer is usually referred to as the casing soil. De Tournefort $(11)^{1}$ as early as 1707 described the use of casing soil in mushroom culture in France. In 1882 Lachaume (4) gave an account of casing procedure used in the underground quarries of France. This procedure was essentially that practiced in France today; powdered rock was screened from the debris that accumulated near the face of the stone quarries in which mushrooms were grown and was mixed with soil in the proportion of three parts of rock powder to one part of soil. The beds were covered with this mixture to a depth of about three-fourths of an inch as soon as the mycelium showed signs of running through the compost.

According to Robinson (9) and Falconer (2), the market gardeners who raised mushrooms in England and the United States prior to 1890 preferred a rich garden loam, which they placed on the beds, from 4 to 10 days after spawning, in a layer 2 to 3 inches deep. Most growers pounded down the soil to a hard surface. By 1915 Duggar (1) and Jackson (3) pointed out that the customary deep casing soil was giving way to the thinner casing adopted by the French 30 years earlier. The need for a very rich loam and firming the soil was also doubted by many growers.

At the present time growers prefer a depth of casing of from threefourths to $1 \frac{1}{4}$ inches. They also agree rather generally that the proper time to case is from 1 to 3 weeks after the mycelium has begun to run in the beds. With regard to the texture of the soil, however, different customs have gained favor in France, England, and the United States. The French still prefer the quarry debris, le bousin, which for them is probably more accessible and free from Mycogone disease than the soil. Ware (12) points out that the English in order to avoid Mycogone have come to use soil from at least 6 inches depth

${ }^{1}$ Italic numbers in parentheses refer to Literature Cited, p. 11.

$98600^{\circ}-39$ 
rather than the surface soil, which is still generally used in the United States. Both heavy clays and sandy soils are usually avoided.

In Germany, Passecker (7) recommends the use of a sandy loam soil applied to a depth of an inch after the spawn has run from 10 days to 2 weeks. He also suggests that only the lower layers of soil be used, in order to avoid diseases resulting from contamination of the surface soil.

In the United States the practice of liming casing soil has evolved in the last 15 years. In England the custom mentioned by Ware (12) of mixing one half of a bushel of lime with each cubic yard of soil is probably much older. Recent recommendations $(6,8,10,12)$, specifying minimum, optimum, and maximum $\mathrm{pH}$ values are largely based on a knowledge of the comparative-yield tests described in this circular.

As far as the writers are aware no replicated yield tests have been previously recorded as a basis for casing-soil practice. In general the criteria for selecting the casing soil and the methods used in applying it are based largely on custom presumably derived from numerous informal empirical tests. The material presented here is the result of replicated field tests made to learn something of the desirability of continuing or modifying certain of these practices.

\section{EXPERIMENTAL METHODS}

The yield tests were in all cases conducted at Arlington Experiment Farm, Arlington, Va., and were made on plots 2 by 5 feet handled uniformly according to standard practice except for the treatment under consideration. In all tests except those recorded in table 2 the plots were laid out in randomized blocks, using entire beds as replicate blocks as suggested in an earlier paper (5). Most of the tests were replicated five times. In the experiments recorded in tables 5 and 6 , the yield was interfered with on one of the beds (blocks) by some factor entirely irrelevant to the experiment, and because of this an entire block was discarded, leaving only four replications. The yields recorded are the sums of about 30 pickings for each crop. As a rule the mushrooms were picked every 2 or 3 days and the beds continued bearing about 3 months. The recorded weights include the weight of the stems in all experiments made subsequent to 1932 . Except where otherwise indicated the standard errors of the experiments were calculated by the analysis of variance method. The standard errors of the treatment means are attached to the tables as footnotes wherever the variance due to the treatments was distinctly greater than variance due to random error.

\section{THICKNESS OF CASING SOIL}

To test the relation of the thickness of casing soil to yield, an experiment was made in which plots were cased to different depths but otherwise were treated as nearly alike as possible. The mean yields per square foot from the 15 plots were as follows: Beds cased 1 inch yielded 1.6 pounds, beds cased 1/1/2 inches yielded 1.5 pounds, and beds cased 2 inches yielded 1.6 pounds. In a subsequent experiment 12 plots were cased 1 inch deep, and 12 comparable plots were cased 2 inches. The mean yields of these two series were nearly identical, 
the former being 2.18 pounds per square foot whereas the latter was 2.15 pounds.

It was quite clear that moderate differences in thickness of casing did not influence yield. The results of these experiments, therefore, are in accordance with the present practice of using approximately 1 inch of casing, as opposed to the older practice of casing 2 or 3 inches thick. The 1-inch depth is preferable to a thicker layer, because it is more economical to apply and because mushrooms appear sooner on 1 -inch casing than on thicker casing. When casing is applied to a depth of less than 1 inch, it is difficult to spread the soil evenly and to maintain a proper moisture content. Furthermore, with shallow casing there is a greater chance of injuring the mycelium in the compost immediately beneath the casing by overwatering. This oftentimes is the cause of a seriously reduced yield.

\section{TIME OF CASING}

Two experiments were made in which the time of casing was the factor considered. The results of these experiments are summarized in tables 1 and 2. These data indicate that both early casing and late casing may sometimes reduce the total yields. When interpreting the results given in table 2 it should be kept in mind that the plots numbered differently were in many cases subjected to different conditions. Therefore, the only variability relevant to the problem lies in differences between the yields of paired plots cased at different times, such as 1 and $1 \mathrm{a}, 2$ and $2 \mathrm{a}$, etc. This was taken into consideration when calculating the odds given at the foot of the table by using the pairing method for calculating the standard error of the means of the differences.

TABLE 1.-Relation of time of applying casing soil to yield of cultivated mushrooms

[Tests made in 1931]

\begin{tabular}{|c|c|c|c|}
\hline Time of casing & $\begin{array}{l}\text { Bed } \\
\text { No. }\end{array}$ & $\begin{array}{l}\text { Yield } \\
\text { per 10 } \\
\text { square } \\
\text { feet }\end{array}$ & $\begin{array}{l}\text { Mean } \\
\text { yield } \\
\text { per } \\
\text { square } \\
\text { foot }^{1}\end{array}$ \\
\hline $\begin{array}{l}\text { Filling time } \\
\text { Spawning time }\end{array}$ & $\begin{array}{l}1 \\
2 \\
3 \\
4 \\
5 \\
1 \\
2 \\
3\end{array}$ & \begin{tabular}{|r|} 
Ounces \\
166 \\
139 \\
180 \\
187 \\
248 \\
182 \\
152 \\
219
\end{tabular} & $\left\{\begin{array}{r}\text { Pounds } \\
1.2\end{array}\right.$ \\
\hline 2 weeks after spawning & $\begin{array}{l}4 \\
5 \\
1 \\
2 \\
3 \\
4 \\
5\end{array}$ & $\begin{array}{l}213 \\
213 \\
257 \\
272 \\
275 \\
238 \\
288\end{array}$ & 1.6 \\
\hline
\end{tabular}

1 Standard error of the mean yield of 5 plots is 0.08 pound per square foot. 
TABLE 2.-Comparison of mushroom yields from beds cased 2 and 4 weeks after spawning

[Tests made in 1931]

\begin{tabular}{|c|c|c|c|c|c|c|c|c|}
\hline \multirow[b]{2}{*}{ Plot No. } & \multicolumn{2}{|c|}{$\begin{array}{l}\text { Yield per } 10 \\
\text { square feet }\end{array}$} & \multirow[b]{2}{*}{ Plot No. } & \multicolumn{2}{|c|}{$\begin{array}{l}\text { Yield per } 10 \\
\text { square feet }\end{array}$} & \multirow[b]{2}{*}{ Plot No. } & \multicolumn{2}{|c|}{$\begin{array}{l}\text { Yield per } 10 \\
\text { square feet }\end{array}$} \\
\hline & $\begin{array}{c}\text { Cased } \\
2 \text { weeks } \\
\text { after } \\
\text { spawn- } \\
\text { ing }\end{array}$ & $\begin{array}{l}\text { Cased } \\
4 \text { weeks } \\
\text { after } \\
\text { spawn- } \\
\text { ing }\end{array}$ & & $\begin{array}{c}\text { Cased } \\
2 \text { weeks } \\
\text { after } \\
\text { spawn- } \\
\text { ing }\end{array}$ & $\begin{array}{l}\text { Cased } \\
4 \text { weeks } \\
\text { after } \\
\text { spawn- } \\
\text { ing }\end{array}$ & & $\begin{array}{c}\text { Cased } \\
2 \text { weeks } \\
\text { after } \\
\text { spawn- } \\
\text { ing }\end{array}$ & $\begin{array}{l}\text { Cased } \\
4 \text { weeks } \\
\text { after } \\
\text { spawn- } \\
\text { ing }\end{array}$ \\
\hline $\begin{array}{l}1 \text { and } 1 \mathrm{a} \\
2 \text { and } 2 \mathrm{a} \\
3 \text { and } 3 \mathrm{a} . \\
4 \text { and } 4 \mathrm{a} .\end{array}$ & $\begin{array}{c}\text { Ounces } \\
288 \\
257 \\
261 \\
238\end{array}$ & $\begin{array}{c}\text { Ounces } \\
274 \\
189 \\
259 \\
168\end{array}$ & $\begin{array}{l}7 \text { and } 7 \mathrm{a} . . . \\
8 \text { and } 8 \mathrm{a} \\
9 \text { and } 9 \mathrm{a} \\
10 \text { and } 10 \mathrm{a} .\end{array}$ & $\begin{array}{l}\text { Ounces } \\
304 \\
227 \\
246 \\
202\end{array}$ & $\begin{array}{c}\text { Ounces } \\
230 \\
247 \\
215 \\
88\end{array}$ & $\begin{array}{l}13 \text { and } 13 \mathrm{a} \\
14 \text { and } 14 \mathrm{a} . \\
15 \text { and } 15 \mathrm{a} .\end{array}$ & $\begin{array}{c}\text { Ounces } \\
252 \\
383 \\
300\end{array}$ & $\begin{array}{c}\text { Ounces } \\
237 \\
275 \\
259\end{array}$ \\
\hline $\begin{array}{l}5 \text { and } 5 a \\
6 \text { and } 6 a\end{array}$ & $\begin{array}{l}139 \\
343\end{array}$ & $\begin{array}{l}141 \\
223\end{array}$ & $\begin{array}{l}11 \text { and } 11 a_{-} \\
12 \text { and } 12 a_{--}\end{array}$ & $\begin{array}{l}382 \\
279\end{array}$ & $\begin{array}{l}212 \\
200\end{array}$ & Mean yield ${ }^{1}$ & 273.4 & 214.4 \\
\hline
\end{tabular}

1 The standard error of the mean of the differences is 13.9 ounces per 10 square feet.

Here again, when considered as a whole, the results of the yield tests were in agreement with general commercial practice. With a

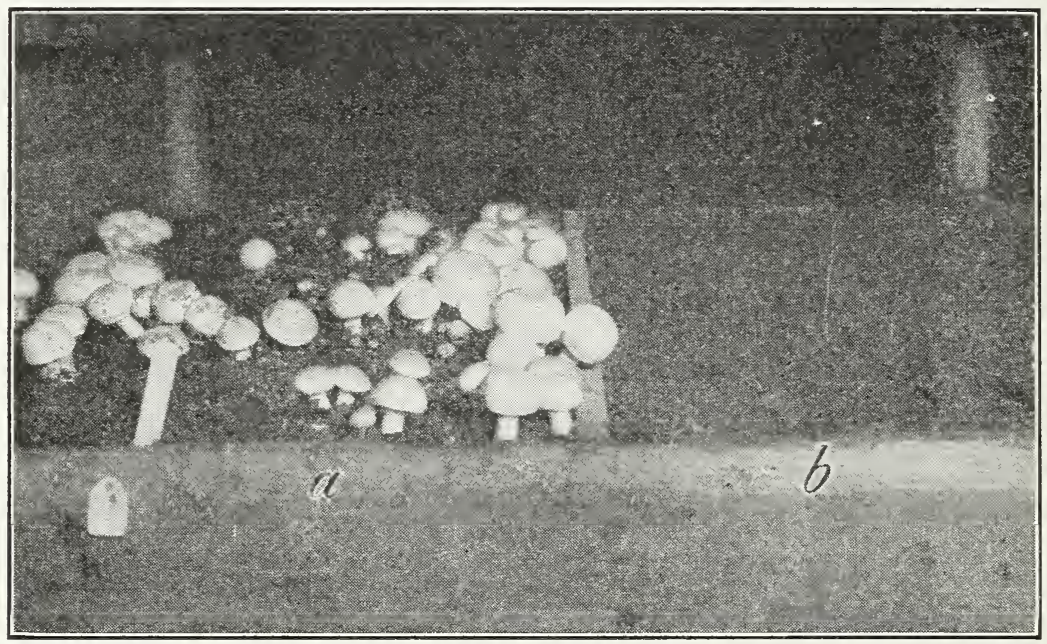

FIGURE 1.-Effect of the reaction of the casing soil on the yield of cultivated mushrooms: $a$, Neutralized soil; $b$, acid soil.

normal run of mycelium in the beds the best yields were obtained when the casing was applied 2 or 3 weeks after spawning. At this time the mycelium had usually appeared on the surface of the beds in patches 6 inches in diameter. Earlier or later casing reduced the yields in certain of the experiments.

\section{REACTION OF THE SOIL}

In the first experiment planned to test the effect of the reaction of the soil on yields, a soil series was made with four different $\mathrm{pH}$ values. This series was made from a Keyport clay loam with a natural reaction of $\mathrm{pH}$ 6.0. The hydrogen-ion concentration was increased with sulphuric acid and decreased with hydrated lime. It is evident from the yield data in table 3 that production was sharply reduced when 
sufficient acid was added to the soil to increase the hydrogen-ion concentration to $\mathrm{pH}$ 4.4. There was some doubt, however, whether the reduced yield was due to an excess of sulphur or to hydrogen ions in the acidified soil.

To answer this question a naturally acid soil was used to make up a series of soils of different $\mathrm{pH}$ values. When beds were cased with these soils the yields shown in table 4 and figure 1 were obtained. The poor yield from the acid soil and the beneficial effects of liming are clearly indicated.

TABLE 3.- Effect on the yield of cultivated mushrooms of treating casing soil with sulphuric acid and with hydrated lime

[Tests made in 1931]

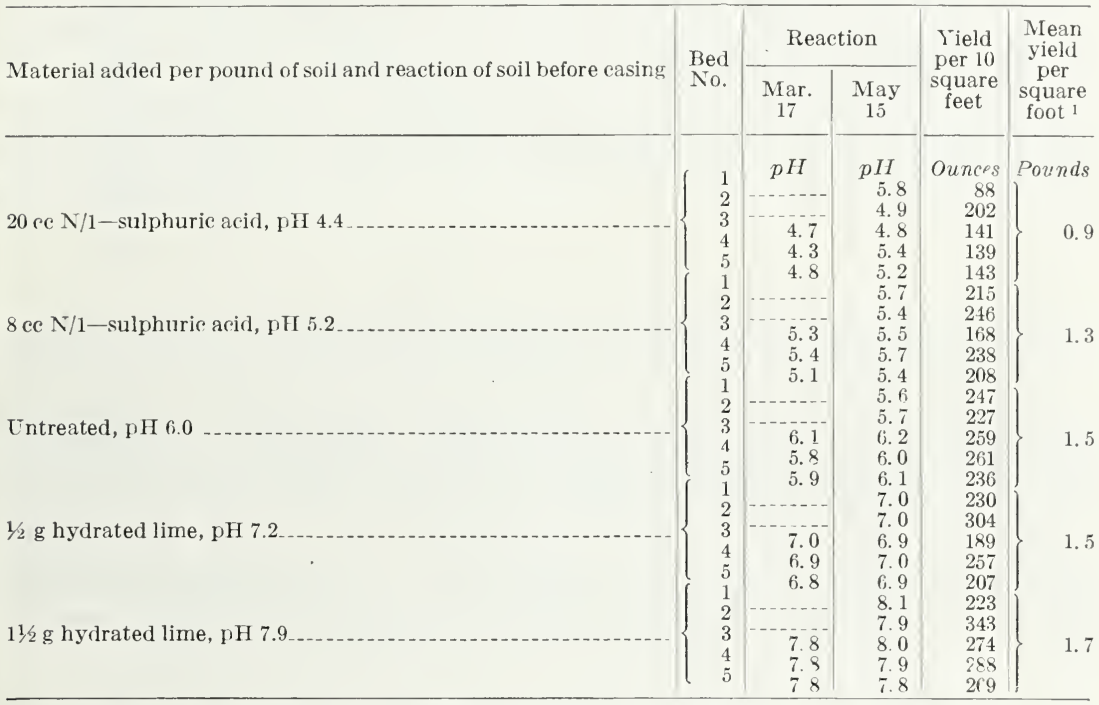

1 Standard error of the mean yield of 5 plots is 0.09 pound per square fcct.

TABLE 4.-Effect on the yield of cultivated mushrooms of adding hydrated lime to an acid casing soil

[Tests made in 1932]

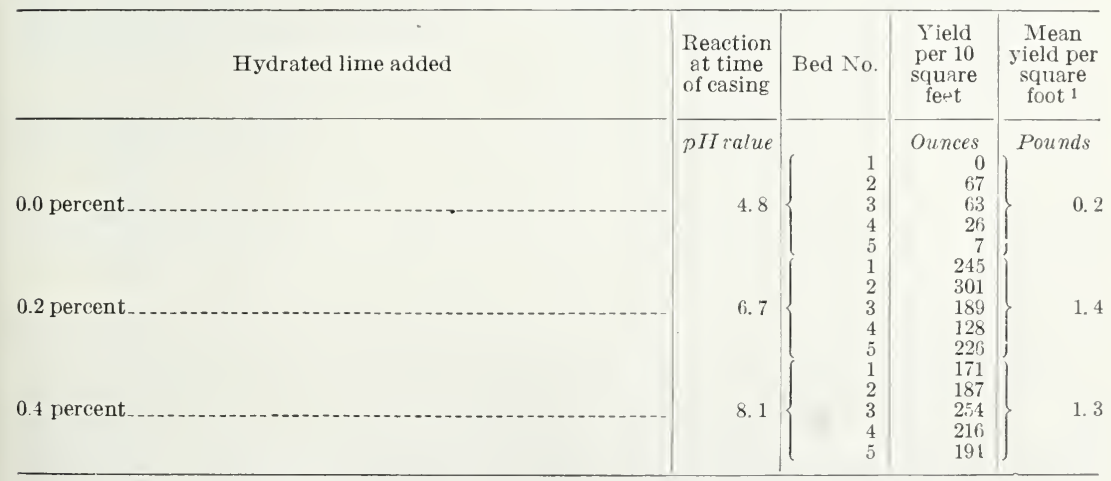

${ }_{1}$ Standard error of the mean yield of 5 lots is 0.12 pound per square foot. 
TABLE 5.-Effect on the yield of cultivated mushrooms of adding excessive amounts of hydrated lime to the casing soil

[Tests made in 1933]

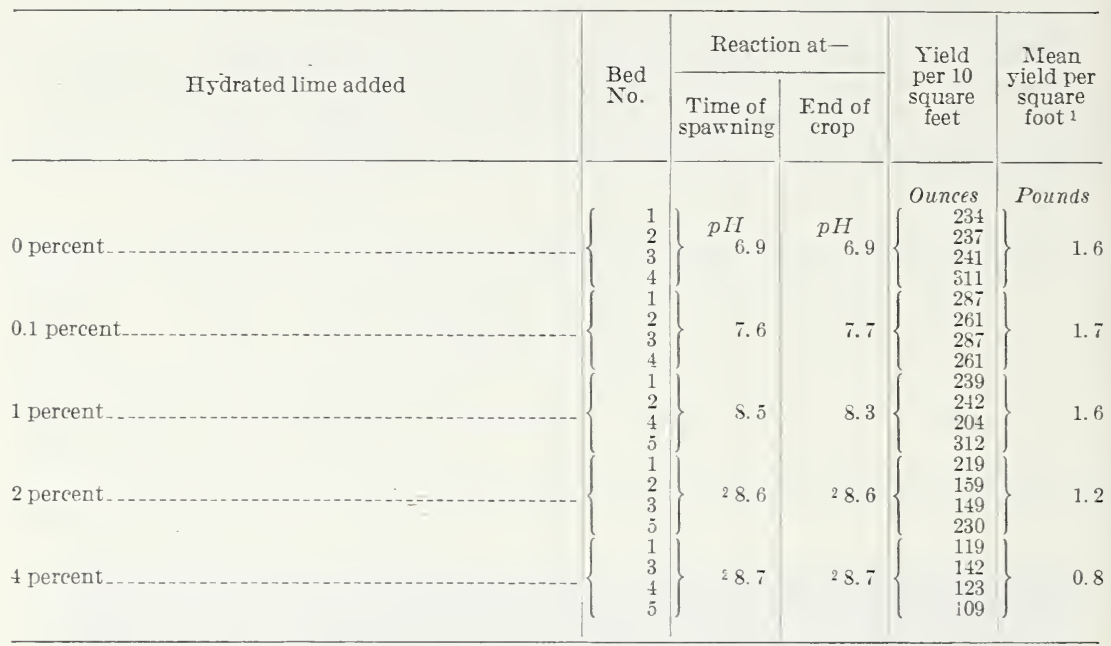

1 Standard error of the mean yield of 4 plots is 0.20 pound per square foot.

2 The actual pH ralue is no doubt higher than the values shown because of the limitations of the quinhydrone method when applied to material having a $\mathrm{pH}$ value above 8.3.

Another series was made up to determine the effect of an excess of hydrated lime (calcium hydroxide) in the casing soil. As shown in table 5 there was a distinct tendency toward a reduction of yield as a result of excessive liming with this material.

The following fall a similar experiment was set up, using highcalcium limestone in place of hydrated lime. In this experiment five times more limestone was used than was necessary, yet there was no statistically significant reduction in yield, as shown in table 6 .

TABLE 6.-Effect on the yield of cultivated mushrooms of adding excessive amounts of limestone to the casing soil

[Tests made in winter of 1933-34]

\begin{tabular}{|c|c|c|c|c|c|c|c|}
\hline Limestone added & $\begin{array}{l}\text { Bed } \\
\text { No. }\end{array}$ & $\begin{array}{l}\text { Yield } \\
\text { per } 10 \\
\text { square } \\
\text { feet }\end{array}$ & $\begin{array}{l}\text { Mean } \\
\text { yield } \\
\text { per } \\
\text { square } \\
\text { foot }\end{array}$ & Limestone added & $\begin{array}{l}\text { Bed } \\
\text { No. }\end{array}$ & $\begin{array}{l}\text { Yield } \\
\text { per } 10 \\
\text { square } \\
\text { feet }\end{array}$ & $\begin{array}{l}\text { Mean } \\
\text { yield } \\
\text { per } \\
\text { square } \\
\text { foot }\end{array}$ \\
\hline $\begin{array}{l}0 \text { percent } \\
6 \text { percent....... }\end{array}$ & $\begin{array}{l}1 \\
2 \\
3 \\
4 \\
1 \\
2 \\
3 \\
4\end{array}$ & $\begin{array}{c}\text { Ounces } \\
263 \\
214 \\
273 \\
122 \\
244 \\
285 \\
180 \\
196\end{array}$ & $\left\{\begin{array}{r}\text { Pounds } \\
1.4 \\
1.4\end{array}\right.$ & 12 percent & $\begin{array}{l}1 \\
2 \\
3 \\
4 \\
1 \\
2 \\
3 \\
4\end{array}$ & $\begin{array}{c}\text { Ounces } \\
228 \\
246 \\
207 \\
201 \\
205 \\
215 \\
152 \\
179\end{array}$ & $\left\{\begin{array}{r}\text { Pounds } \\
1.4 \\
1.2\end{array}\right.$ \\
\hline
\end{tabular}

The tests as a whole clearly indicated that soil approximately neutral in reaction vielded better than acid soil or excessively alkaline soil. Any $\mathrm{pH}$ value between $\mathrm{pH} 5.5$ and $\mathrm{pH} 8.0$ seemed suitable. It is evident that hydrated lime may be injurious if added to the soil in excess. On the other hand, limestone (more than 90 percent cal- 
cium carbonate) was found to be just as effective in neutralizing the soil as hydrated lime, and there seemed to be practically no danger of injuring the crop from adding an excess. ${ }^{2}$

At the present time many growers neutralize the soil with hydrated lime, and after the crop comes into bearing some of them fill the holes on the bed with a mixture of one-tenth hydrated lime to nine-tenths soil. They also water the beds occasionally with limewater. In the opinion of the writers it is just as effective, and safer practice, to add from 2 to 5 percent of limestone (high in calcium carbonate) to the original casing soil and to the soil used for filling holes in the bed. The custom of using hydrated lime instead of limestone seems to be based on an erroneous opinion which is prevalent among growers, that limestone must be added to casing soil several months before using. In the experience of the writers, powdered limestone neutralized the soil sufficiently for practical purposes overnight. Thus the slower action of the limestone is more of a theoretical objection than a practical one. Furthermore, an excess of limestone may be safely added, and the continued buffering effect of the residual limestone is beneficial in that it neutralizes the organic acid produced by the mushroom mycelium.

\section{TEXTURE OF SOIL}

In the initial experiment to determine the effect of the texture of the soil on yield, soils of four different textures were used: Clay loam, loam, sandy loam, and sand. Each soil was limed to approximate neutrality. As apparent from table 7, there was an unmistakable tendency for the heavier textured soils to support better yields of mushrooms than the light soils. The clay loam yielded twice as much as the sand.

TABLE 7.-Relation of the texture of casing soil to the yield of cultivated mushrooms

[Tests made in winter of 1934-35]

\begin{tabular}{|c|c|c|c|}
\hline Texture and source of soil & $\begin{array}{l}\text { Bed } \\
\text { No. }\end{array}$ & $\begin{array}{l}\text { Yield } \\
\text { per } 10 \\
\text { square } \\
\text { feet }\end{array}$ & $\begin{array}{l}\text { Mean } \\
\text { yield } \\
\text { per } \\
\text { square } \\
\text { foot }{ }^{1}\end{array}$ \\
\hline Keyport clay loam, Arlington, Va & $\begin{array}{l}1 \\
2 \\
3\end{array}$ & $\begin{array}{r}\text { Ounces } \\
356 \\
208 \\
344\end{array}$ & $\begin{array}{r}\text { Pounds } \\
2.0\end{array}$ \\
\hline Keyport loam, Beltsville, Md & $\begin{array}{l}0 \\
1 \\
2 \\
3\end{array}$ & $\begin{array}{l}303 \\
331 \\
357\end{array}$ & 2. 0 \\
\hline Sandy loam, Arlington, Va............ & $\begin{array}{l}4 \\
1 \\
2 \\
3\end{array}$ & $\begin{array}{l}206 \\
229 \\
250\end{array}$ & 1.5 \\
\hline Sand, Arlington, Va & $\begin{array}{l}5 \\
1 \\
2 \\
3\end{array}$ & $\begin{array}{l}254 \\
142 \\
267 \\
214\end{array}$ & 1.0 \\
\hline & $\begin{array}{l}4 \\
5\end{array}$ & $\begin{array}{l}114 \\
109\end{array}$ & \\
\hline
\end{tabular}

1 Standard error of the mean yield of 5 plots is 0.09 pound per square foot.

2 This statement refers only to limestone high in calcium carbonate. Both hydrated lime and limestone are frequently high in magnesium. The effect of an excess of magnesium in the soil has not been systematically investigated, but it has the reputation among commercial growers of being harmful. 
A more extensive series of soils was compared in a later test which is summarized in table 8. In this experiment there again seemed to be a significant tendency for the heavier soils to yield better than the sandy soils. A comparatively high yield was obtained from neu-

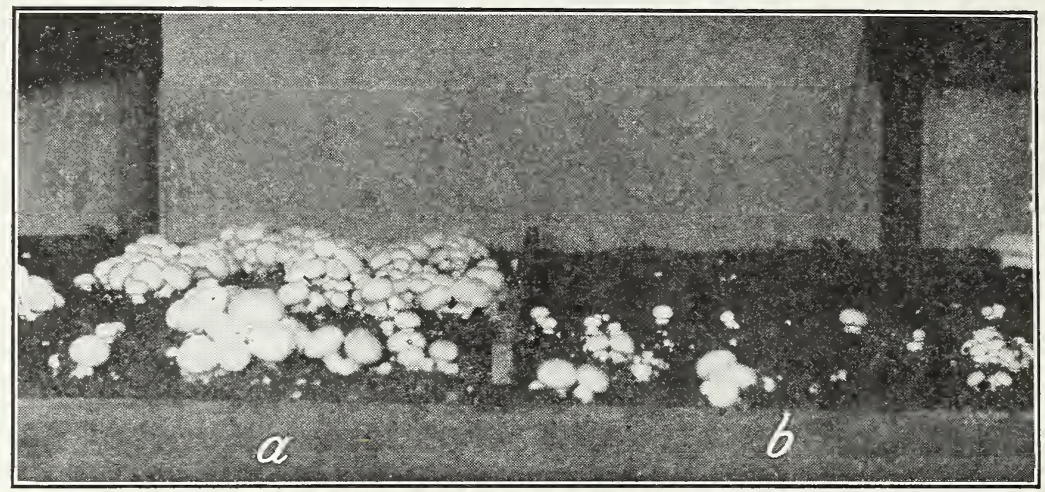

FIGURE 2.-Effect of texture of casing soil on the first break of mushrooms, Arlington Experiment Farm, 1934-35: $a$, Keyport clay loam; $b$, sandy loam.

tralized hyperhumus, but the mushrooms from the beds cased with this material were inferior in quality because of excessive spotting. Differences in earliness as well as in yield as a result of soil texture are strikingly illustrated in figure 2 .

TABLE 8.-Relation of texture of casing soil to yield of cultivated mushrooms

[Tests made in winter of 1935-36]

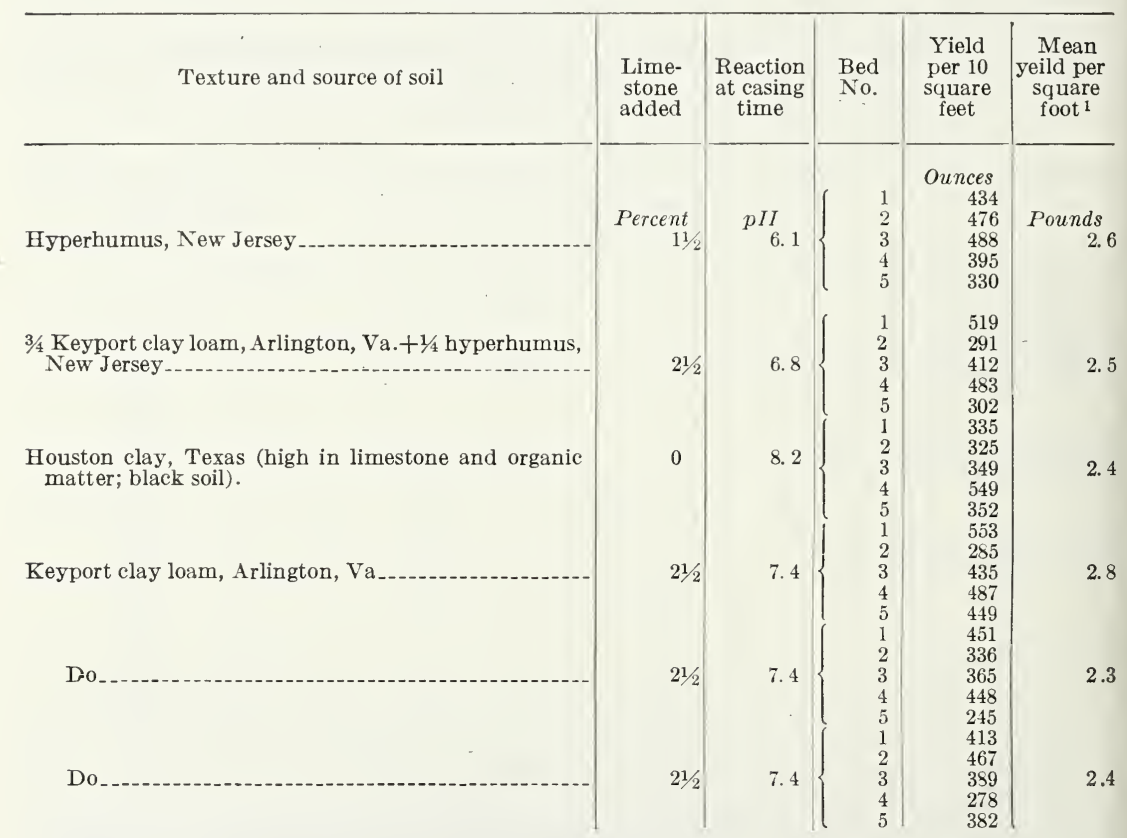

${ }_{1}$ Standard error of the mean is 0.15 pound per square foot. 
if such a soil were acid, it would be necessary to neutralize it with ground limestone.

In practice most growers would be well advised to select loam soils of medium texture wherever possible and avoid the heavy clay loams. In exceptional cases in which the grower is thoroughly familiar with soil texture and the factors controlling physical conditions in soil, it may be advisable to attempt to increase yields by experimenting with soils of heavier texture.

\section{HEAT STERILIZATION OF SOIL}

During the past 5 years several growers in eastern Pennsylvania have been steaming their casing soil to eradicate Mycogone. It is generally known that steaming certain soils may be detrimental to succeeding crops of higher plants. Therefore, preliminary experiments were carried out to learn something of the effect on yield of mushrooms of heating the casing soil at different temperatures. In the first experiment, Keyport clay loam was divided into five portions. One of these was placed in a layer 10 inches deep in an unused bed at the top of the mushroom house and allowed to warm up during the "peak heat," which was about $130^{\circ} \mathrm{F}$. The other portions of soil were placed in cotton sacks in a special heating chamber and raised to the temperatures $150^{\circ}, 170^{\circ}, 190^{\circ}$, and $212^{\circ}$. The plots cased with soils heated in the chamber yielded only half as much as those cased with soil heated in the mushroom house at $130^{\circ}$. Similar results were obtained in a subsequent experiment. In this experiment the soil heated in cotton sacks was damaged in certain cases even when the temperature did not exceed $135^{\circ}$.

These experiments leave little doubt that serious loss in yield may result from the heating of casing soil under certain conditions. This question is being investigated further. Meanwhile a more critical attitude should be assumed toward heat treatment of mushroom casing soil than has been the case in the past. In some cases heat treatment may be desirable and beneficial; in others it is clearly harmful.

\section{SUMMARY}

Comparative tests indica te that casing practice may have a considerable influence on mushroom yields.

The thickness of the soil was not an important factor. The customary 1-inch casing seemed preferable.

Two or three weeks after spawning seemed to be the best time for casing.

Soil approximately neutral in reaction gave better yields than very acid soil or excessively alkaline soil. Ground limestone was found to be more nearly foolproof and therefore preferable to hydrated lime for neutralizing casing soil.

In general, heavy soils yielded better than sandy soils. Clay loams or even clays seemed preferable whenever their physical condition was such that they did not puddle or cake on the bed.

With the soil tested there was a noticeable reduction in yield as a result of heat sterilization under certain conditions. 
(1) DUGGAR, B. M.

\section{LITERATURE CITED}

1915. Mushroom growing. 250 pp., illus. New York.

(2) Falconer, Williair.

1910. MUSHROOMS, HOW TO GROW THEM. A PRACTICAL TREATISE ON MUSHROOM CULTURE FOR PROFIT AND PLEASURE. 169 pp., illus. New York.

(3) JACKson, A. V.

1909. THE SECRETS OF MUSHROOM GROWING SIMPLY EXPLAINED. 64 pp., illus. Chicago.

(4) Lachaume, JeAN.

1882. LE CHAMPIgNON DE COUCHE; CULTURE BOURgeOISE ET COMMERciale, récolte et conservation. Ed. 2, 108 pp. Paris.

(5) Lambert, Edmund B.

1934. SIZE AND ARRANGEMENT OF PLOTS FOR YIELD TESTS WITH CULTI-

(6) LAмBert, L. F. vated mushrooms. Jour. Agr. Research 48: 971-980, illus.

1933. CULTIVATION OF THE MUSHROOM; GUIDE AND REFERENCE MANUAL FOR THE SUCCESSFUL MUSHROOM GROWER. 57 pp., illus. Coatesville, $\mathrm{Pa}$.

(7) Passecker, Freidrich.

1932. MIODERNE CHAMPIGNONKULTUR. 34 pp., illus. Wien.

(8) Rettew, G., Raymond, Gahm, Otis, E., and Divine, Floyd W.

1935. mandal of MUShroom cUlture. 106 pp., illus. West Chester, $\mathrm{Pa}$.

(9) Robinson, W.

1891. MUSHROOM CULTURE; ITS EXTENSION AND IMPROVEMENT. 172 pp., illus. New York.

(10) Styer, J. Franklin.

1933. Modern MUShroom culture. 99 pp., illus. West Chester, Pa.

(11) Tournefort, Joseph Pitton de

1730. OBSERVATIONS SUR LA NAISSANCE ET SUR LA CULTURE DES CHAMPIgNons. Hist. l'Acad. Royale Sci. [Paris] 1707: 46-50.

(12) WARE, W. M. [Also in Mém. Acad. Sci. Paris 1707: 58-66.]

1935. mushroom-Growing. [Gt. Brit.] Min. Agr. and Fisheries Bull. 34, Ed. 3, 54 pp., illus. 


\section{ORGANIZATION OF THE UNITED STATES DEPARTMENT OF AGRICULTURE WHEN THIS PUBLICATION WAS LAST PRINTED}

Secretary of Agriculture

Under Secretary

Assistant Secretary

Coordinator of Land Use Planning and Director of Information.

Director of Extension Work.

Director of Finance

Director of Personnel

Director of Research.

Solicitor

Agricultural Adjustment Administration.

Bureau of Agricultural Economics.

Bureau of Agricultural Engineering

Bureau of Animal Industry

Bureau of Biological Survey

Bureau of Chemistry and Soils

Commodity Exchange Administration

Bureau of Dairy Industry.

Bureau of Entomology and Plant Quarantine

Office of Experiment Stations.

Farm Security Administration.

Food and Drug Administration.

Forest Service

Bureau of Home Economics

Library

Bureau of Plant Industry

Bureau of Public Roads

Soil Conservation Service

Weather Bureau.
Henry A. Wallace.

M. L. Wilson.

Harry L. Brown.

M. S. Eisenhower.

C. W. WARBURton.

W. A. Jump.

ROY F. HENDRICKSON.

JAMES T. JARDine.

Mastin G. White.

H. R. Tolley, Administrator.

A. G. Black, Chief.

S. H. McCrory, Chief.

Johin R. Mohler, Chief.

Ira N. Gabrielson, Chief

Henry G. Knight, Chief.

J. W. T. Duver, Chief.

O. E. ReEd, Chief.

Lee A. Strong, Chief.

JAMES T. JARDINe, Chief.

W. W. Alexander, Administrator.

Walter G. Campbell, Chief.

Ferdinand A. Silcox, Chief.

Louise Stanley, Chief.

Claribel R. Barnett, Librarian.

E. C. Auchter, Chief.

Thomas H. MacDonald, Chief.

H. H. Bennett, Chief.

F. W. Reichelderfer, Chief.

This circular is a contribution from

Bureau of Plant Industry_........... E. C. Auchter, Chief.

Division of Mycology and Disease Survey_- H. A. Enson, Principal Pathologist, in Charge.

Division of Soil Microbiology_..._._._. C. Тном, Principal Mycologist, in Charge. 
